\title{
Biological functions of selenium and its potential influence on Parkinson's disease
}

\author{
JOEL H. ELLWANGER ${ }^{1}$, SILVIA I.R. FRANKE ${ }^{2}$, DIANA L. BORDIN ${ }^{1}$, DANIEL PRÁ ${ }^{2,3}$ and JOÃO A.P. HENRIQUES ${ }^{1,4}$
}

\author{
${ }^{1}$ Programa de Pós-Graduação em Biologia Celular e Molecular, Centro de Biotecnologia, Universidade Federal do Rio \\ Grande do Sul/UFRGS, Campus do Vale, Prédio 43421, Av. Bento Gonçalves, 9500, 91501-970 Porto Alegre, RS, Brasil \\ ${ }^{2}$ Programa de Pós-Graduação em Promoção da Saúde, Universidade de Santa Cruz do Sul/UNISC, Bloco \\ 42, sala 4206, Av. Independência, 2293, Universitário, 96815-900 Santa Cruz do Sul, RS, Brasil \\ ${ }^{3}$ Departamento de Biologia e Farmácia, Universidade de Santa Cruz do Sul/UNISC, Bloco 12, sala \\ 1206, Av. Independência, 2293, Universitário, 96815-900 Santa Cruz do Sul, RS, Brasil \\ ${ }^{4}$ Instituto de Biotecnologia, Universidade de Caxias do Sul/UCS, Rua Francisco Getúlio \\ Vargas, 1130, 95070-560 Caxias do Sul, RS, Brasil
}

Manuscript received on August 7, 2015; accepted for publication on September 28, 2015

\begin{abstract}
Parkinson's disease is characterized by the death of dopaminergic neurons, mainly in the substantia nigra, and causes serious locomotor dysfunctions. It is likely that the oxidative damage to cellular biomolecules is among the leading causes of neurodegeneration that occurs in the disease. Selenium is an essential mineral for proper functioning of the brain, and mainly due to its antioxidant activity, it is possible to exert a special role in the prevention and in the nutritional management of Parkinson's disease. Currently, few researchers have investigated the effects of selenium on Parkinson's disease. However, it is known that very high or very low body levels of selenium can (possibly) contribute to the pathogenesis of Parkinson's disease, because this imbalance results in increased levels of oxidative stress. Therefore, the aim of this work is to review and discuss studies that have addressed these topics and to finally associate the information obtained from them so that these data and associations serve as input to new research.
\end{abstract}

Key words: neurodegeneration, nutrition, oxidative stress, Parkinson's disease, selenium.

\section{INTRODUCTION}

The influence of diet on the prevention, etiology and treatment of various diseases is well established, as exemplified by several recent studies (Barnard et al. 2014, Chiva-Blanch et al. 2014, Elenberg and Shaoul 2014, Kondo et al. 2014, Squitti et al. 2014). Among the nutrients obtained from the diet, it is known that selenium (Se) is important for healthy human metabolism and that it is

Correspondence to: João Antonio Pêgas Henriques

E-mail: henriques@cbiot.ufrgs.br/pegas.henriques@gmail.com involved in the pathophysiology of many diseases, such as cancer, type-2 diabetes, viral diseases, cardiovascular disease, muscle disorders, male infertility, and neurological disorders, among others (Rayman 2012, Hatfield et al. 2014, Roman et al. 2014). Little is known about the role of Se in pathologies that affect the central nervous system. However, Se has important antioxidant functions (Maldonado et al. 2012, Liu et al. 2013, Li et al. 2014) and neuroprotective actions ( $\mathrm{Lu}$ et al. 2014, Naziroğlu et al. 2014, Şenol et al. 2014, Yang et al. 2014). Therefore, Se in imbalance levels could be 
significantly involved in the pathophysiology of neurodegenerative diseases.

One of the most common neurodegenerative disorders in the population worldwide is Parkinson's disease (PD), which primarily affects the elderly (Pringsheim et al. 2014). The factors that contribute to a delay or acceleration of the progression of PD are not completely established. Evidence has shown that cellular oxidative damage is one of the major possible causes of PD (Seet et al. 2010, Dias et al. 2013, Hwang 2013, LeWitt et al. 2013, Gaki and Papavassiliou 2014).

Considering that Se has antioxidant activity and oxidative damages are most likely involved in the pathogenesis of PD, studying the role of the mineral on this disease is a promising direction, especially because an association between Se and PD has been poorly investigated. Therefore, the aim of this work is to investigate and discuss the possible effects of Se on PD based on experimental and theoretical studies. Thus, according to relevancy, review and hypothesis articles were also used in this study. In the first part of this review, we present the roles of Se in the maintenance of human health and in nervous system homeostasis, as well as a brief discussion regarding the appropriate levels of Se that should be consumed to maintain human health. The second part describes the pathophysiology and biomarkers of PD, their relationships with oxidative stress, and the roles of diet and specific micronutrients in the disease. Finally, in the third part of this review, the potential influence of Se on PD is discussed, with an emphasis on the role of Se in the locomotor system and brain dysfunction.

\section{SELENIUM}

In 1817, Se was discovered by Swedish chemist Jöns Jacob Berzelius (Boyd 2011), and currently, it is known that Se is a trace element that is indispensable for the maintenance of human health and affects body metabolism in normal and pathological situations (Rayman 2012). However, many aspects of Se still need to be clarified, including the optimal levels of Se that should be consumed to achieve its beneficial effects and avoid the detrimental effects, as well as the role of this nutrient in the treatment and prevention of neurodegenerative diseases such as PD. These topics will be covered in the following section.

\section{DIETARY SOURCES AND NUTRITIONAL}

RECOMMENDATIONS

Se is an essential nutrient, and the human diet is a natural source for obtaining it in relevant amounts. The dietary sources of Se are quite diverse, including meat, milk, eggs and vegetables (Lemire et al. 2010). The amount of Se present in most vegetables depends on the amount of the mineral present in the soil in which the plant was cultivated. Therefore, plants grown in soils rich in Se have high mineral levels, whereas the opposite is also true (Combs 2001, Mehdi et al. 2013). It was recently demonstrated that in monsoonal China, precipitation has an important effect on the distribution of Se in soil (Blazina et al. 2014). This fact demonstrates that populations living in specific regions of the world are susceptible to high or low consumption of Se, and the amounts vary according to environmental conditions that modify the mineral content of the soil where they live. This influence is greatest where the importation of food from various locations is lower, because it makes the consumption of local foods greater, to the detriment of food from various geographical and environmental origins.

Among the foods considered as sources of $\mathrm{Se}$, the Brazil nut is rich in this nutrient. According to Cominetti et al. (2012), a single Brazil nut may have up to $290 \mu \mathrm{g}$ of Se (about 5-fold the daily dietary requirement). Therefore, this food can be used to increase levels of this mineral in the blood (Stockler-Pinto et al. 2010). This information is clinically important because it demonstrates that the inclusion of controlled amounts of Brazil nuts in the diet can be a way to supplement the mineral 
in patients with specific needs of Se. Thus, the use of non-food supplements of this mineral is not required. However, it is important to mention that in Brazil, the Brazil nut is not widespread in the food culture of all regions of the country. Additionally, the Brazil nut is an expensive product, which becomes an obstacle for people wishing to acquire it.

The recommendations for daily Se intake are relatively easy to be achieved through a balanced diet according to the gender and age of each individual. For adult men and women, $55 \mu \mathrm{g}$ of Se/ day is considered the ideal amount to be consumed. This recommendation remains unchanged for the elderly people and is lower for children. Quantities greater than $400 \mu \mathrm{g}$ of Se/day (recommendation for adults) are not indicated by threatening intoxication (IOM 2000). Cases of Se poisoning are not common but can cause signs such as hair and body hair alterations, nails and skin abnormalities, garlic breath (Stockler-Pinto et al. 2010), lethargy, and amyotrophic lateral sclerosis (Vinceti et al. 2014).

In addition to food sources of Se to increase body levels of the mineral, other factors must be considered, such as the bioavailability of the nutrient. The bioavailability of Se will depend on various factors, such as the mineral absorption rate that varies according to the type of food consumed and the interaction with other nutrients (NavarroAlarcon and Cabrera-Vique 2008, Gad and Abd El-Twab 2009, Thiry et al. 2013). The organic forms of Se are more bioavailable than inorganic Se (Daniels 1996, Rayman et al. 2008). Therefore, in individuals requiring the supplementation of the mineral, using Se supplementation in organic form (for example: wheat Se, selenomethionine or high-Se-yeast) seems to be more advantageous than using supplements containing Se in inorganic form (selenate or selenite) (Rayman et al. 2008). Furthermore, there is evidence that Se consumed through food is better absorbed than Se from mineral supplements. Approximately $80 \%$ of dietary Se can be absorbed, which varies according to the type of food source of the mineral (Navarro-Alarcon and Cabrera-Vique 2008). An in vitro study using three types of supplements of Se (Se-enriched yeast, selenate-based food supplement and selenite-based food supplement) showed that $14 \%$ (from selenate supplement) was the highest rate of bioavailability achieved (Thiry et al. 2013). Notwithstanding, the bioavailability of Se either via food or via supplements deserves further studies.

\section{BIOLOGICAL ROLES OF SELENIUM}

Se deficiency has been associated with some diseases such as Keshan disease (a cardiomyopathy that affects people living in regions with soil poor in Se) (Loscalzo 2014). Se deficiencies are also related to genomic instability (Arigony et al. 2013). Additionally, Se is able to perform epigenetic changes through DNA methylation and histone modifications (Speckmann and Grune 2015). Complex pathological situations such as infection by human immunodeficiency virus (Ellwanger et al. 2011, Sudfeld et al. 2014) and cancer (Yakubov et al. 2014) also appear to be influenced by body levels of Se. In this context, the antioxidant function of Se (Maldonado et al. 2012, Arigony et al. 2013, Liu et al. 2013, Li et al. 2014) involves protecting from and slowing the development of diseases that involve oxidative damage to cellular components.

The biological activity attributed to Se is exercised through selenoproteins, which are proteins that have a selenocysteine residue in the active site (Hatfield et al. 2014). The selenoproteins play varied and important activities in the body, such as selenium transport (Burk and Hill 2009), endoplasmic reticulum homeostasis (Shchedrina et al. 2011), immunomodulation, regulation of apoptosis (Roman et al. 2014), and control of the cellular redox state (Arigony et al. 2013). There are currently twenty-five selenoproteins identified in humans, which include Selenoprotein P (SelP), Selenoprotein W (SelW), Selenoprotein H (SelH), Selenoprotein M (SelM), Selenoprotein R (SelR), 
Selenoprotein N (SelN), Selenoprotein S (SelS) and the selenoproteins from the families of Iodothyronine deiodinase (DIOs), Thioredoxin reductase (TrxRs) and Glutathione peroxidase (GPxs). All are involved in metabolic functions to prevent and/or combat diseases (Roman et al. 2014). Although all these selenoproteins have an important role in cellular homeostasis, the families of antioxidant enzymes should be highlighted. The family of GPxs should be particularly focused because the inappropriate activity of GPxs has been reported as a factor that strongly correlates with the nutritional deficiency of Se, which contributes to oxidative stress and therefore the emergence of diseases, including neuronal disorders (Mehdi et al. 2013, Pillai et al. 2014). Among the eight enzymes described in this family, five (GPx1, GPx2, GPx3, GPx4 and GPx6) are selenoproteins, and they are involved in the detoxification of hydrogen peroxide and lipid hydroperoxides, among other types of reactive species. In these reactions, the tripeptide
GSH is used as a reducing agent (Lei et al. 2007, Brigelius-Flohé and Maiorino 2013, Smeyne and Smeyne 2013). It is important to mention that in the GPxs family, GPx5, GPx7 and GPx8 are non-Se congeners (Brigelius-Flohé and Maiorino 2013). A brief demonstration of the activity of Se-dependent glutathione peroxidase is shown in Figure 1.

The action of selenoproteins is related to diet. Se ingested through food is incorporated into selenoproteins, and the activity of these proteins depends on the levels of Se ingested (Weeks et al. 2012, Zhang et al. 2013). This information suggests that quantities of Se ingested through food can influence the activity of glutathione peroxidase, in addition to blood levels of the mineral (Cominetti et al. 2012, Giacosa et al. 2014). If the level of Se in the body is low, the cells cannot synthesize selenoproteins properly (Ferguson et al. 2012). If the activity level of selenoproteins with antioxidant action is sufficient to combat the level of oxidizing agents generated by the body or by the envi-

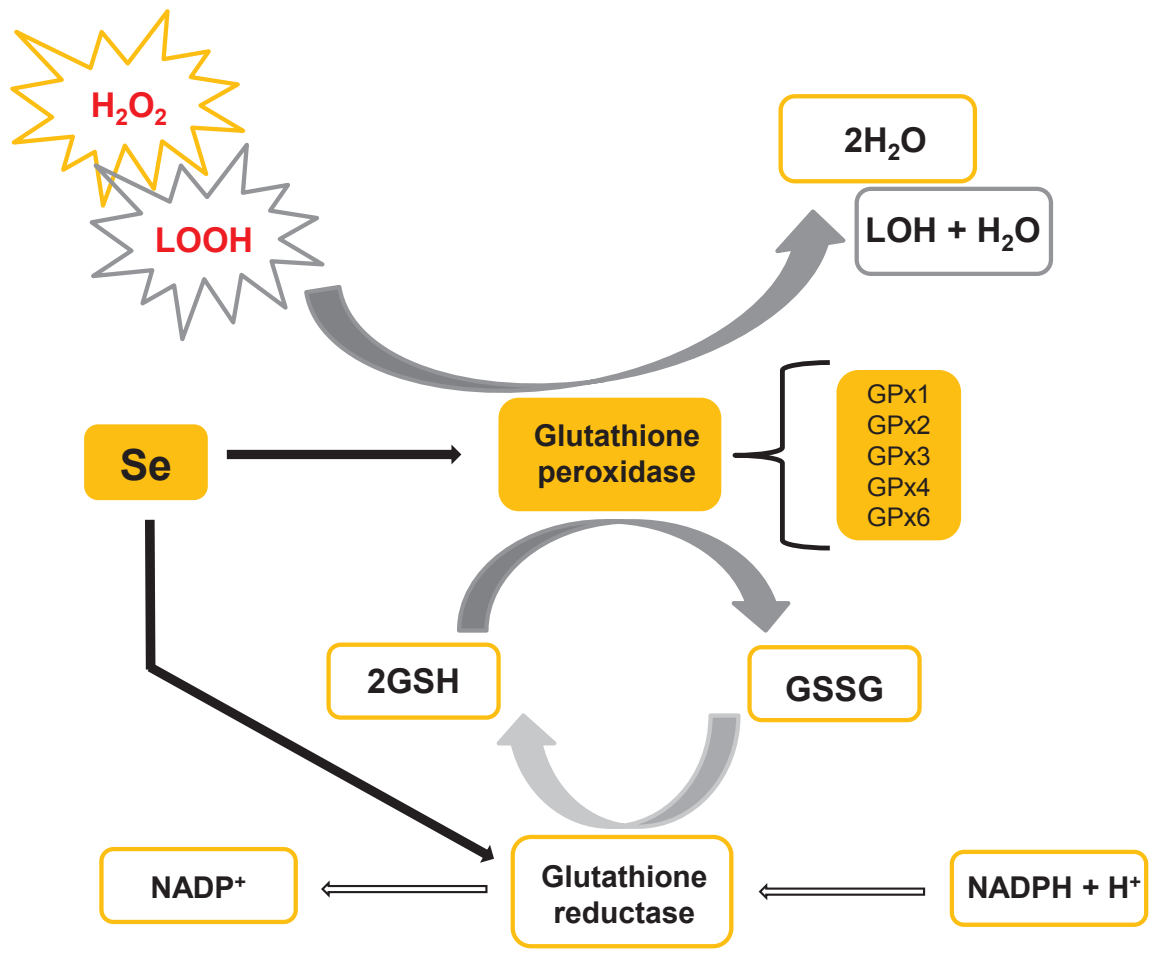

Figure 1 - Detoxification of hydrogen peroxide $\left(\mathrm{H}_{2} \mathrm{O}_{2}\right)$ and lipid peroxides ( $\left.\mathrm{LOOH}\right)$ by Sedependent glutathione peroxidase. Glutathione peroxidase activity requires two molecules of the tripeptide GSH, which is restored by the enzyme glutathione reductase. 
ronment, the oxidative stress is avoided. However, if there is an imbalance between the activity of antioxidant enzymes and the levels of oxidizing agents, oxidative stress will occur, which will result in damage to cellular biomolecules (Othman and El Missiry 1998, Brenneisen et al. 2005, Rahmanto and Davies 2012, Song et al. 2014, Yakubov et al. 2014). These events are schematically summarized in Figure 2. Therefore, it is important to mention that individuals who are exposed to environmental stimuli or have lifestyles that exacerbate oxidative stress should be aware of Se dietary recommendations, and this information must be a prominent topic in dietary planning for these individuals (Thomson 2004). To date, there is no specific dietary requirement defined for individuals with high oxidative stress levels, and future studies are need to set such levels.

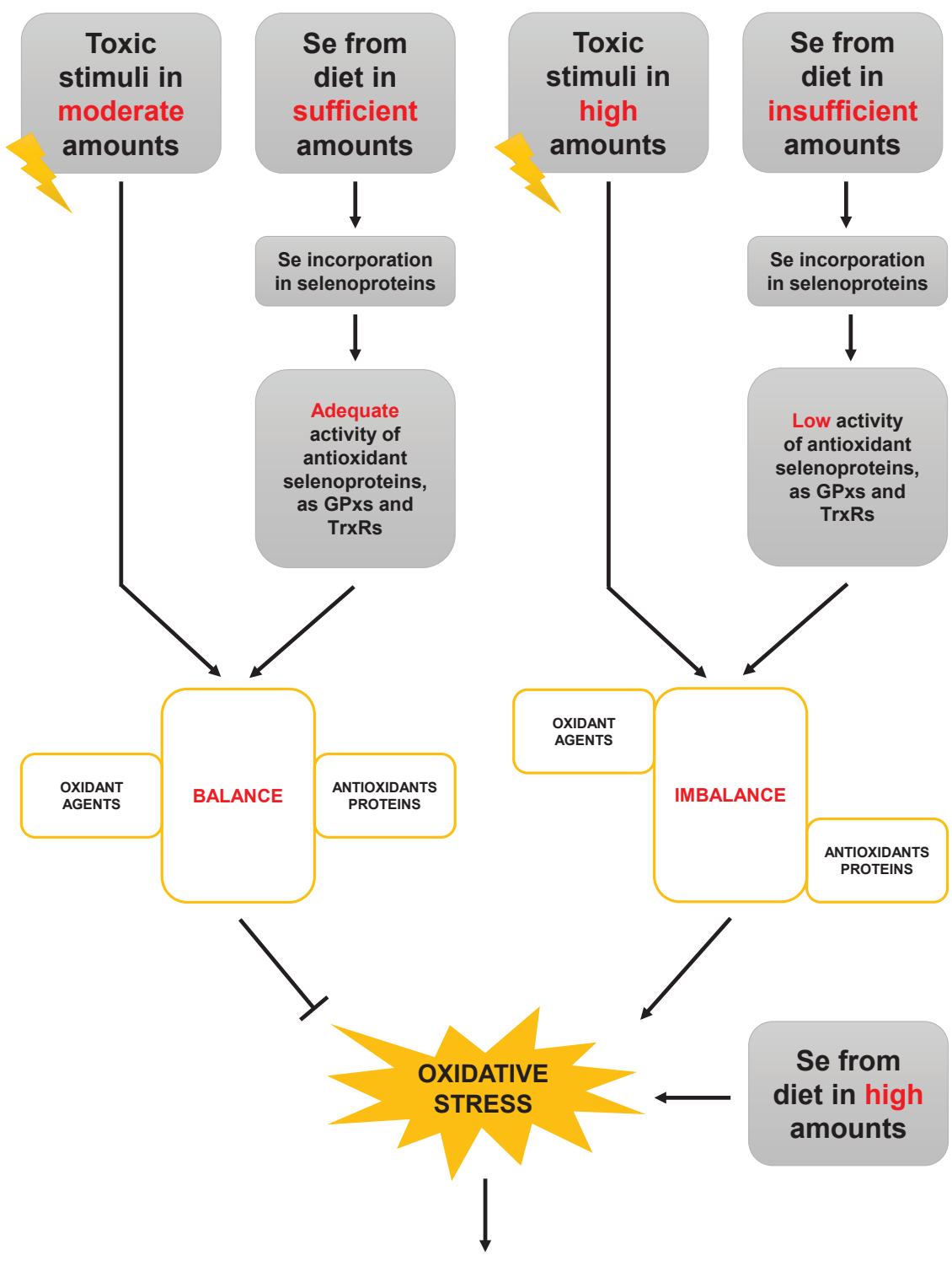

DAMAGE TO BIOMOLECULES

Figure 2 - Main events that influence the antioxidant activity of Se. The Se antioxidant activity occurs through selenoproteins, which are influenced by Se levels obtained through diet. 


\section{Potential NOXIOUS EFFECTS OF SELENIUM OVERLOAD}

It is important to mention that despite Se influence on the metabolism of various human diseases by its antioxidant action, the role of this mineral cannot always be protective or combat injury inherent to a pathological condition. Se may not often act protectively or even beneficially, as demonstrated by Maraldi et al. (2011) in a test performed in vitro using human neuron cells and by Estevez et al. (2012), who showed that a high dose of Se can induce oxidative stress in cholinergic neurons of Caenorhabditis elegans. Recent results indicated that the supplementation of $200 \mu \mathrm{g}$ of Se/day (from L-selenomethionine) is not recommended for preventing prostate cancer (Kristal et al. 2014). This information calls attention to the importance of not considering the mineral only as a protective agent when introduced into a research protocol. Depending on the quantities used, type of Se chosen and experimental conditions, Se could have detrimental effects, similar to those mentioned above.

AdEQUATE SELENIUM LEVELS FOR PREVENTING DisEASES

Studies that investigated the effect of Se on various parameters related to health or disease in humans have used various approaches. These studies used food questionnaires (Lemire et al. 2011, Vieira Rocha et al. 2014), measured mineral levels in plasma (Zhao et al. 2013) and breast-milk (Flax et al. 2014), and incorporated supplements (Kristal et al. 2014, Sudfeld et al. 2014). Regarding the use of Se supplements in research with adult humans, additional doses up to $200 \mu \mathrm{g}$ of Se/day may be appropriate. This value represents an amount of mineral approximately 4 times higher than the recommended value (can be used to evaluate the effects of high doses of the mineral) but much less than the amount that could pose a risk to health (IOM 2000, Ellwanger et al. 2011, Yakubov et al. 2014). Clinically, Se supplementation may be important for individuals from populations that live in geographical areas where the mineral is not easily consumed through diet or have genetic variations that alter the metabolism of the mineral (Pitts et al. 2014). Methodological approaches using various animal models (Li et al. 2013, Lu et al. 2014) or cell cultures (Lamarche et al. 2004, Maraldi et al. 2011) are useful for answering questions related to the effects of Se on health/disease but cannot be investigated by testing in humans due to ethical and methodological reasons.

\section{SELENIUM AND THE NERVOUS SYSTEM}

Se is also essential for proper brain function (Schweizer et al. 2004, Cardoso et al. 2015). Several studies have demonstrated that this mineral influences various pathologies affecting the central nervous system. In elderly patients, low levels of Se in plasma are related to a reduction in neurological activity, such as coordination (Shahar et al. 2010). Se may also influence behavioral development (Watanabe and Satoh 1994) and psychological aspects, such as mood (Benton 2002) and cognition (Steinbrenner and Sies 2013). Se in the form of organic compounds could act as an antipsychotic (Machado et al. 2006).

In addition to influencing the functioning of the brain and various diseases of the central nervous system, Se has neuroprotective effects demonstrated by several experimental approaches (Lu et al. 2014, Naziroğlu et al. 2014, Şenol et al. 2014, Yang et al. 2014). This information supports the concept that Se has a key role in the development and/or progression of neurodegenerative diseases, acting as a neuroprotective agent. However, considering the complexity of these diseases and the various influences that Se can play, the mechanisms by which this mineral acts in these diseases still need to be investigated. More studies are also needed to understand the specific roles of selenoproteins and the effects of Se intake on neurodegenerative diseases (Steinbrenner and Sies 2013). Therefore, 
a better understanding of the role of Se in the pathogenic mechanisms of PD is important.

\section{PARKINSON'S DISEASE}

PD was first described by James Parkinson in 1917 (for historical aspects of the disease, see the review published by Goetz (2011)). Currently, PD is the second most common neurodegenerative disease in the world, and Alzheimer's disease is the most frequent (De Lau and Breteler 2006). PD primarily affects the elderly, occurring in approximately $1 \%$ of the population over 60 years (Nussbaum and Ellis 2003, De Lau and Breteler 2006) but can also occur less frequently in younger individuals (Lees et al. 2009, Mehanna et al. 2014).

Geographically, the distribution of the disease in the world slightly varies. A recent study reported that among individuals aged between 70 and 79 years, PD is more prevalent in Australia and countries of Europe and North America compared with individuals from Asia (Pringsheim et al. 2014). Differences among sexes were also observed. The prevalence and health impact of PD is higher in men (Lubomski et al. 2014). In addition to physical and psychological harm caused to patients, PD has a great economic impact due to the high medical costs of preventing and combating the disease and loss of workforce. Approximately 14 billion dollars were spent combating it in the United States of America alone in 2010 (Kowal et al. 2013).

PD neuropathology is characterized by the degeneration of dopaminergic neurons that communicate to the substantia nigra pars compacta of the midbrain to the striatum and affect neurons of the nigrostriatal pathway. The cells linking the substantia nigra to the putamen are the most affected. The presence of cytoplasmic inclusions known as Lewy Bodies are also part of PD neuropathology (Dauer and Przedborski 2003, Lees et al. 2009, Dickson 2012). Other brain structures may also be affected in the disease. For example, evidence obtained by neuroimaging exams indicate that the cerebellum of patients suffering from PD is hyperactive (Yu et al. 2007), but the role of the cerebellum and other structures in this disease is still poorly understood and should be further studied.

\section{DIAGNOSIS AND BIOLOGICAL MARKERS OF PARKINSON'S DISEASE}

There is no specific biochemical test to indicate the presence of PD. The diagnosis is made primarily from signs and clinical features presented by the patient (Nussbaum and Ellis 2003, Lees et al. 2009) and can only be confirmed at postmortem examination (Nussbaum and Ellis 2003). Recently it was demonstrated that quantify the expression of $\alpha$-synuclein in skin biopsies have the potential to be used as an additional tool for the diagnosis of PD (Rodríguez-Leyva et al. 2014). Some of the clinical signs used to establish the diagnosis of PD are tremor at rest, postural instability, muscular rigidity, and difficulty in initiating movements (akinesia) or continuing them (bradykinesia), among others that affect movement (Lees et al. 2009, Mazzoni et al. 2012).

Because there are no specific laboratory tests to diagnose the disease, the search for biomarkers for the presence of PD is extremely important, and several markers related to oxidative stress have been suggested to be diagnostic of PD. LeWitt et al. (2013) reported that the 3-Hydroxykynurenine from cerebrospinal fluid might be useful for this purpose. The oxidized DJ-1 protein has also been suggested as a potential biomarker for PD (Saito 2014). Kouti et al. (2013) demonstrated the potential for the use of nitric oxide and peroxynitrite levels as biomarkers to monitor the progression of the disease. Additionally, in a recent study, Ide et al. (2015) noted that the levels of vitamin $\mathrm{C}$ in lymphocytes could be used to monitor the progression of PD. In seeking biomarkers, it is important to remember that determining the susceptibility genes for PD will help discover which molecules serve as potential biomarkers for disease (Labbé and Ross 2014). 
The involvement of genetic factors in the onset of PD is quite relevant. In a recent meta-analysis conducted by Nalls et al. (2014), six new risk loci for PD were described: SIPA1L2, INPP5F, MIR4697, GCH1, VPS13C and DDRGK1. In meta-analysis studies, Dai et al. (2014) reported that $T N F-1031$ polymorphism is a possible risk factor for $\mathrm{PD}$, and Wang et al. (2014) concluded that the null genotype of GSTT1 is also related to increased risk of the development of PD, at least in Caucasians. The roles of the genes parkin, DJ-1 and PINK-1 in the susceptibility to PD (Hauser and Hastings 2013) should be highlighted, as well as the LRRK2 gene (Martin et al. 2014). Genetic mutations affecting the PINK1 and LRRK2 proteins are related to mitochondrial dysfunction and the formation of reactive oxygen species (Zuo and Motherwell 2013), which are events involved in PD pathophysiology.

OXIDATIVE STRESS AND OTHER MOLECULAR

DYSFUNCTIONS IN PARKINSON'S DISEASE

Although genetic factors are very important in the pathogenesis of $\mathrm{PD}$, it is believed that the interaction between genetic and environmental factors determines whether the disease develops (Chai and Lim 2013, Searles Nielsen et al. 2013, Smeyne and Smeyne 2013, Pringsheim et al. 2014). It is known, for example, that occupational and environmental exposure to pesticides (such as paraquat and rotenone) can trigger PD (McCormack et al. 2002, Tanner et al. 2011, Wang et al. 2011, Kamel 2013, Baltazar et al. 2014). This factor exemplifies how environmental factors associated with oxidative stress should not be overlooked in investigating the causes of PD and should be considered together with the genetic characteristics of each individual. However, the interactions between these two factors are not well established.

Oxidative stress seems to be crucial for PD development (Dias et al. 2013, Hwang 2013, LeWitt et al. 2013, Gaki and Papavassiliou 2014, Kirbas et al. 2014). Additionally, DNA damage
(Giovannelli et al. 2003), deficiency in the repair of these damages (Jeppesen et al. 2011, Canugovi et al. 2013), lipid peroxidation (Sanders and Greenamyre 2013) and mitochondrial dysfunction (Yan et al. 2013) are other important events in the physiopathology of PD. Neuroinflammation also appears to have an involvement in the etiology (Niranjan 2014) and progression of this disease (Taylor et al. 2013).

Biomarkers indicated that oxidative damage is increased in patients suffering from $\mathrm{PD}$, reinforcing the relationship between this injury and the disease (Seet et al. 2010). A treatment against the oxidative stress in PD is still not established, but to be effective, this molecular insult should be a target of treatment in the early stages of the disease (Celardo et al. 2014). However, it is interesting to note there is doubt whether oxidative stress is a cause or a consequence of the loss of dopaminergic neurons in PD (Sanders and Greenamyre 2013), so further studies on this aspect should be conducted. As cited by Tsang and Chung (2009), a detailed understanding of how oxidative stress influences the pathophysiology of PD will help develop better strategies to treat the disease.

Mitochondrial dysfunction is another important molecular event associated with PD (Yan et al. 2013). More specifically, oxidative stress related to the impairment of complex I of the mitochondrial respiratory chain and mitochondrial DNA mutations are mentioned as causal factors of the disease (Subramaniam and Chesselet 2013). Müller et al. (2013) demonstrated a relationship between the presence of Lewy bodies and mitochondrial DNA damage. In this context, the results of the study conducted by Sanders et al. (2014) support the use of mitochondrial DNA damage as a biomarker for the vulnerability of dopaminergic neurons in PD. However, this aspect should be better characterized, and further studies investigating the role of mitochondria in PD are needed. 
New insights into the pathophysiology of the PD have been described. Recently, Janda et al. (2012) and Zhang et al. (2015) have discussed the association between defects in the process of autophagy and PD. Wen et al. (2014) reported the involvement of proteins that induce cell cycle reentry (CDK5/RKIP/ERK pathway) causing neuronal death in PD. Brenner (2014) hypothesized that the deterioration of melanin in the cells of the substantia nigra may be possible involved in the development and progression of PD. The relationship between PD and nucleolar stress has also been discussed (Parlato and Liss 2014). The suggestions of the involvement of all these molecular processes in PD leads to further discussion on the causes and factors that are involved in disease progression, and therefore, possible new therapeutic targets are hitherto unimagined. However, more experimental investigations using robust methodology are needed to support these new findings.

The dopamine replacement by using Levodopa has been widely used for three decades in the treatment of PD (Dexter and Jenner 2013). Levodopa reduces lymphocyte DNA damage in these individuals (Cornetta et al. 2009). However, it is important to highlight that despite the existence of treatment, currently there is still no cure for the disease (Dexter and Jenner 2013).

Although dopamine can act as an antioxidant (Yen and Hsieh 1997), there is evidence that this neurotransmitter contributes to the generation of neuronal toxicity. In dopaminergic cells, normal dopamine metabolism involving the tyrosine hydroxylase enzyme is responsible for producing oxygen radicals that damage biomolecule cells (Adams Jr et al. 2001). This fact helps to explain the high oxidative stress generated in the dopaminergic neurons.

DIET, MiCRONUTRIENTS AND THE PREVENTION OF PARKINSON'S DISEASE

In elderly patients, the relationship between oxidative stress and nutritional status has been well established (Moreira et al. 2014), but the influence of nutrition, specifically in PD, has been poorly explored. It is likely that an imbalance in the consumption of macronutrients seems to be a predisposing factor for the disease, and it has been reported in a meta-analysis conducted by Chen et al. (2014) that overweight is a possible risk factor of PD. In this context, it was suggested that in men, the consumption of milk and cheese could increase the risk for development of PD, although these data still need to be confirmed by future studies using strong methodologies (Jiang et al. 2014). Kamel et al. (2014) showed that high consumption of n-3 polyunsaturated fatty acids (PUFAs) associated with low consumption of saturated fats could help reduce the risk for developing PD. The authors described that a diet poor in PUFAs or with high amounts of saturated fat might increase the susceptibility to neurotoxic agents associated with the pathogenesis of PD. However, Dong et al. (2014) reported a positive association between n-6 PUFAs intake and the risk for developing $\mathrm{PD}$, but this is a weak association that needs to be confirmed in future studies. The same authors cited that n-3 PUFAs have anti-inflammatory effects and n-6 PUFAs have pro-inflammatory effects. This information could justify the results from these two studies, but the relationship between PUFAs and PD cannot be fully understood and deserves to be studied in detail.

The intake of micronutrients could also be a factor influencing the pathophysiology of the disease. Recently, Stelmashook et al. (2014) described that the imbalance of copper and zinc can influence the mechanisms of pathogenesis of $\mathrm{PD}$. High intake of non-heme iron associated with low vitamin $\mathrm{C}$ intake may represent a higher risk for PD (Logroscino et al. 2008). Some authors report a beneficial use of the micronutrients in PD. The administration of folates and vitamins B6 and B12 could be used in a supplemental way and associated with the conventional treatment 
to delay the progression of the disease and/or improve the quality of life of the patients with PD (Dorszewska et al. 2014). The use of these nutrients could contribute to healthy nutritional status of patients and would help in combating the molecular events that lead to disease, but these supplementation strategies using various nutrients should be clinically investigated and elaborated very carefully. Additionally, vitamin D could have a neuroprotective effect, influencing the symptoms and possibly the development and progression of the disease (Peterson 2014). The influence of food and specific micronutrients in PD is still unclear. These results reinforce the idea that the relationship between nutrition and PD is complex and requires more studies in people to clarify these aspects. However, the food and nutrition management in patients suffering from PD is very important so that they can achieve or maintain a healthy nutritional status. This goal will ensure adequate intake of micronutrients (especially those antioxidants as Se), preserving other aspects of health that will allow people to lead a healthy, normal life.

\section{THE INFLUENCE OF SELENIUM ON PARKINSON'S DISEASE}

Recently, our research group experimentally investigated the role of $\mathrm{Se}$ in an experimental model of PD in rats and induced by the herbicide paraquat (Ellwanger et al. 2015). This work has helped to test the hypothesis that Se could aid in preventing PD if used previously to the emergence of disease or perhaps on patients suffering from early stages of PD. This hypothesis was initially presented in a work published by Cadet in the 1980s (Cadet 1986), who proposed the use of Se associated with vitamin E. To the best of our knowledge, this type of supplementation had not been investigated (Se alone or Se plus vitamin $\mathrm{E}$ in paraquat-induced models). Our findings indicated that Se protected against bradykinesia (locomotor damage) and DNA damage in lymphocytes of rats in the tested animal model of PD induced by paraquat. A study performed by Khan (2010) in an animal model of PD in mice demonstrated that Se also reversed, at least partially, the toxic effects (dopamine depletion) caused by 1-methyl4-phenyl-1,2,3,6-tetrahydropyridine (MPTP), that has the 1-methyl-4-phenylpyridinium (MPP+) as active metabolite, a molecule very similar to paraquat (Dauer and Przedborski 2003). This protective effect of Se on dopamine in animal models of PD is further strengthened by the results of the work conducted by Zafar et al. (2003) who used the 6-hydroxydopamine (6-OHDA) to induce the model in rats. Additionally, a report of a test using embryonic stem cell transplantation in brains of rats submitted to a model of 6-OHDA-induced PD described that Se can also protect against inflammation generated in this therapy (Tian et al. 2012). Although the results of these studies are quite relevant, it is important to note that these authors investigated the effects of the mineral in experimental models of the disease, which differ in several aspects from PD that occurs naturally. Therefore, further studies are needed to extrapolate the results to humans. In all experimental studies cited above, the Se used in the tests was sodium selenite, an inorganic form of Se. However, the Se used in other experimental strategies varies in terms of chemical structure, which further complicates the extrapolation of results to humans. In this context, it is important to mention that the type of Se used in future pharmacological therapies should be considered, and the potential therapeutic use of organoselenium compounds should be further explored (Nogueira and Rocha 2011). For example, ebselen, an organic form of Se, has a known strong antioxidant function (Miorelli et al. 2008) and therefore has the potential to combat oxidative stress that occurs in PD. Thereby, studies investigating the antioxidant potential of ebselen are encouraged. 


\section{SELENIUM AND THE LOCOMOTOR SYSTEM}

Because locomotor damage is a main feature of $\mathrm{PD}$, it is interesting to analyze the results obtained from studies that evaluated the influence of Se on various aspects of the locomotor system. High levels of Se in the human organism protect the motor function in individuals exposed to mercury (Lemire et al. 2011), whereas the serum levels of Se appear to also be associated with the walking speed in elderly ( $\geq 65$ years) women in a positive way (Alipanah et al. 2009). In the treatment of Restless Leg Syndrome, a human disorder based on the dopamine system that causes limb movements and could be associated with PD (Gao et al. 2010, Rahimdel et al. 2012), a daily dose of $50 \mu \mathrm{g}$ of Se improved symptoms (Rahimdel et al. 2012). In animal models, Yeo et al. (2008) reported that Se (sodium selenite) protects the locomotor system of rats submitted to damage to the spinal cord. This protection of locomotion was also obtained by Zafar et al. (2003) and by our research group (Ellwanger et al. 2015), both using other animal models (PD models) and evaluating various aspects of locomotion, as previously mentioned. The administration of physiological doses of sodium selenite may contribute to the physical performance of rats, as assessed by levels of glycogen in liver after a swimming test (Akil et al. 2011). However, a recent study by Marcondes Sari et al. (2014) did not find changes in locomotor function evaluated by open-field test in mice that received p-chloroselenosteroid. It is difficult to compare the studies that evaluated the effects of Se on locomotion, because there are few experimental approaches and they differ. Therefore, it is not possible to obtain consistent conclusions or extrapolate them to the locomotor effects observed in patients with PD.

SELENIUM IMBALANCE AND BRAIN DYSFUNCTION

Selenoproteins are also essential to brain function (Chen and Berry 2003), and the depletion of these proteins seems to be related to the pathophysiology of PD (Zhang et al. 2010). This mechanism suggests that analyzing the results of studies that investigated the interaction between Se and selenoproteins and its relation with the brain and PD is also relevant. In this context, the roles of glutathione peroxidase and selenoprotein P are briefly discussed in this review.

Rats deficient in Se have lower glutathione peroxidase (a Se-dependent enzyme) activity in the brain (Sanchez et al. 2003). Additionally, the reduction of the antioxidant defenses in the brain caused by Se deficiency is attributed to the decrease of glutathione peroxidase activity (Castaño et al. 1997). Kim et al. (1999) observed that dietary Se (sodium selenite) attenuated the neurotoxicity in mice treated with methamphetamine evaluated by dopamine depletion in the striatum and substantia nigra. The authors also attributed this neurotoxicity prevention principally to the activity of glutathione peroxidase. These data were supported by evidence that neurotoxicity (high oxidative stress) induced by methamphetamine can be mitigated by maintaining glutathione peroxidase activity through the use of Se (Imam and Ali 2000, Barayuga et al. 2013). These results demonstrate that glutathione peroxidase plays a key role in protecting against the degeneration of dopaminergic neurons, and therefore could be involved in the physiopathology of PD (Smeyne and Smeyne 2013).

Selenoprotein $\mathrm{P}$ is also critical to neuronal functioning (Peters et al. 2006) and the normal level of Se in the brain (Burk et al. 2014). The deletion of this protein causes inadequate uptake of Se by the brain, as demonstrated by Hill et al. (2003) in a study using mice. More recently, other studies using animals showed that the deletion of selenoprotein $\mathrm{P}$ causes the degeneration of the brain cells (Caito et al. 2011, Byrns et al. 2014). By examining post mortem brain tissue from PD patients, Bellinger et al. (2012) demonstrated that selenoprotein $\mathrm{P}$ expression decreased in the substantia nigra of these individuals compared 
with controls. However, the authors also described that the protein was increased relative to the total number of cells. All this evidence indicates that Se may influence neurodegeneration by altering the activity of selenoproteins, such as glutathione peroxidase and selenoprotein P. In other words, the concept that Se has an indirect action in the protection process in addition to its nonselenoprotein antioxidant function is reinforced (Imam and Ali 2000, Hart et al. 2013).

Se deficiencies can modify the functioning of dopaminergic neurons (Watanabe et al. 1997), which are the main cells that are affected in PD. Paradoxically, Se deficiency may increase the activity of tyrosine hydroxylase and dopamine production (Romero-Ramos et al. 2000). These data suggest that the deficiency of the mineral can trigger compensatory activity by dopamine production in response to a situation in which its depletion (due to Se deficiency) is previously established. In a study conducted in the 1990s by Aguilar et al. (1998), no differences in cerebrospinal fluid levels of Se were observed between PD patients and control subjects. Qureshi et al. (2006) reported an increased cerebrospinal Se level in PD patients compared to controls. Zhao et al. (2013) also reported higher Se levels in PD patients compared with control individuals, but the study evaluated plasma levels of the mineral. Additionally, reduced Se was not found in people with PD if the nutrient was measured in lymphocytes (Mischley et al. 2012) or by serum levels (Aguilar et al. 1998, YounesMhenni et al. 2013). However, low serum levels of Se in individuals with PD compared with controls were reported by Nikam et al. (2009). Ultimately, according to the results obtained by the cited studies, it is not possible to make a direct relationship between Se status and PD after the disease has already been established. This finding highlights that the use of the mineral for preventing disease could be a promising strategy.

Paradoxically, increased deaths due to PD have been reported in men who lived in an area where the drinking water was rich in inorganic Se (Vinceti et al. 2000). These data were reinforced by the findings of a study in which PD patients consumed Se-rich foods with higher frequency than control subjects (Ayuso-Peralta et al. 1997). These data highlight that $\mathrm{Se}$ in high amounts is prooxidant (Letavayová et al. 2006, Brozmanová et al. 2010). Currently, cultural habits that favor the consumption of some specific Se-rich food or their easy availability may be responsible for excessive consumption of the mineral. The results of these studies also demonstrate the augmented complexity of investigating the effects of Se from food consumption, in which synergism and antagonism between nutrients occur, compared with seeking correlations between disease and levels of the mineral or studying controlled intake of the mineral through supplements. More studies evaluating the relationship between PD and the consumption of Se through food are needed, especially to provide technical and scientific information for the elaboration of better diets for the elderly population.

Finally, from the information presented and discussed here, the probable/hypothetical relationship between the nutritional status of Se and PD is summarized in a schematic model presented in Figure 3. The events shown in this hypothetical model, as well as the relationship between them, represent the evidence most strongly established in the literature. As described in this review, new events and interactions have also been suggested and discussed by several authors but were not included in the model because more research is needed to confirm and further characterize their roles in the pathophysiology of PD.

\section{CONCLUSIONS}

Despite being a mineral required in low amounts for the human body, an adequate level of Se might improve several aspects of human health. Se deficiencies are rarely reported, making it 


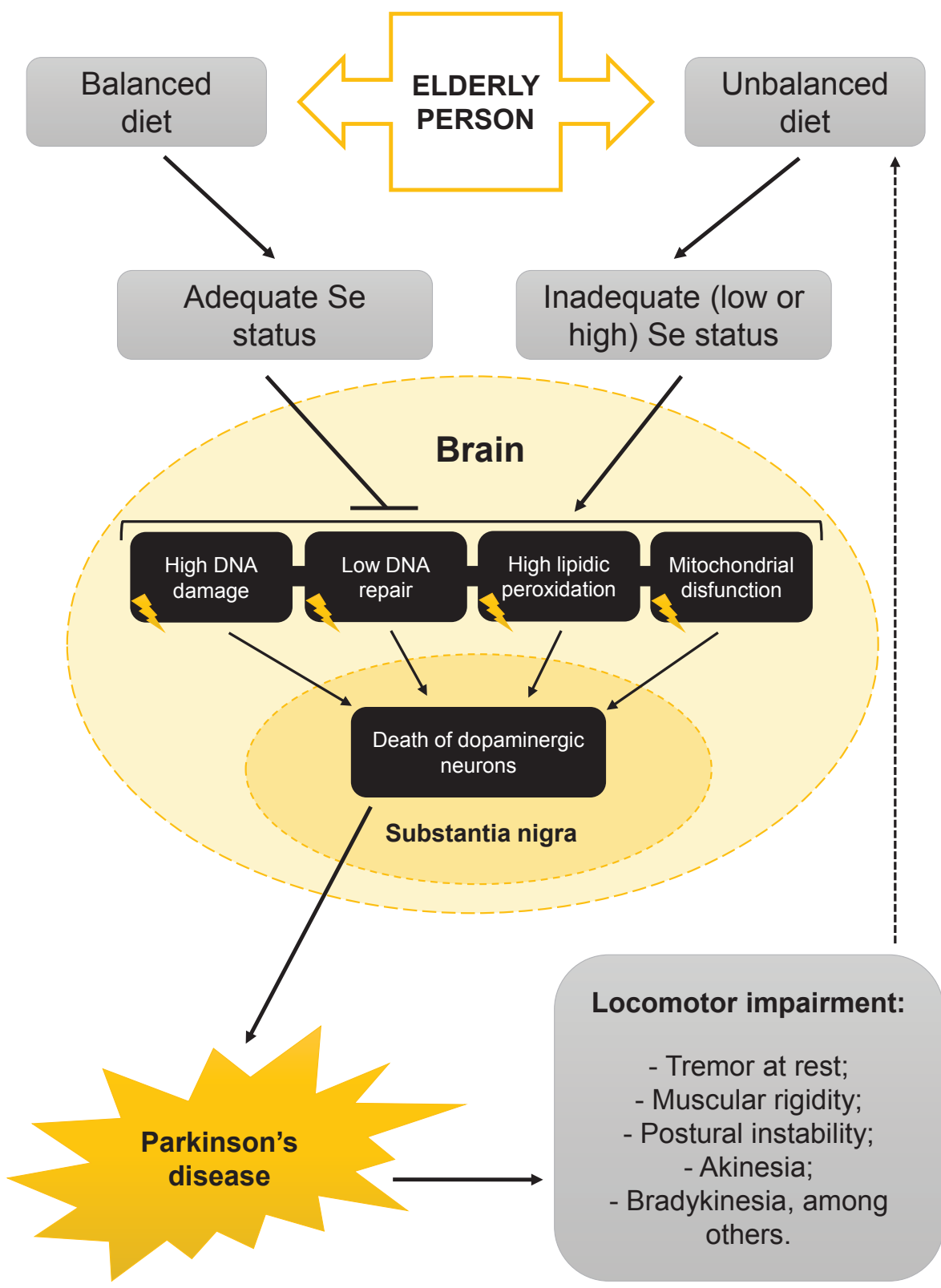

Figure 3 - Probable (hypothetical) relationship between nutritional status of Se and events that culminate in PD. Elderly individuals are susceptible to dietary imbalances that may cause inadequate nutritional Se. Inadequate levels of Se (high or low) in the brain cause co-interacted events that culminate in the death of dopaminergic neurons in the substantia nigra; however, adequate levels of Se protect against these events. The neuronal death of dopaminergic neurons leads to PD, which affects the locomotor system. This locomotor impairment can cause damage to the lives of individuals affected by disease as well as inadequate diet.

appear that it is a situation of little importance. However, subclinical deficiencies may impact cellular metabolism and cause changes that can lead to various diseases, possibly including neurodegenerative conditions, if accumulated and associated with other environmental and genetic factors. Moreover, Se in excess is also associated with pathological situations. Therefore, we stress 
the importance of maintaining Se consumption in the recommended doses by IOM (2000) (55 - 400 $\mu \mathrm{g}$ /day for adults), either through food or through supplements (if they are needed). This information is especially important for nutritionists and other health professionals who work with the nutritional management of subjects who are healthy as well as subjects with pathological conditions. People who live in geographical regions where the soil is rich or poor in mineral levels should receive more attention in regard to the quantities of Se ingested.

Among neurodegenerative diseases that could be physiologically affected by Se levels, PD is prominent. Evidence has shown that PD is most likely the result of an association between environmental and genetic factors. People who have genetic characteristics associated with high disease risk should avoid environmental/occupational exposure to pesticides and should maintain a diet with adequate levels of antioxidants (including Se) and attitudes that can slow and prevent the onset of disease. Although the death of dopaminergic neurons has been described as a main cause of PD, new studies have shown that several other molecular events may be involved in the pathogenesis of the disease. This fact demonstrates that the causal events of PD are still unclear and should be further studied.

Studies in humans and in experimental models suggest that Se could be involved in the pathophysiology of PD and that the mineral, if used in appropriate doses, could protect against this disease. This effect is mainly due to the antioxidant characteristics of Se and its ability to fight the molecular events that culminate in neuronal death. However, the results of some studies have not supported these findings. These conclusions underscore the importance of conducting studies that aim to explore and establish the role of Se in PD in more detail. Accordingly, it will be possible to confirm or not the beneficial effects of using Se for the prevention or in the dietary treatment of PD. However, in the elderly, it is clear that a proper diet for age and proper Se intake according to recommendations is essential not only for the prevention of PD but for several other diseases, whether neurodegenerative or not. Lastly, based on the evaluation and discussion of the studies presented in this review, it can be suggested that continued investigations into the influence of Se on PD are important.

\section{RESUMO}

A doença de Parkinson é caracterizada pela morte dos neurônios dopaminérgicos, principalmente na substância negra, e causa sérias disfunções locomotoras. É provável que o dano oxidativo às biomoléculas celulares esteja entre as principais causas da neurodegeneração que ocorre nessa doença. O selênio é um mineral essencial para o adequado funcionamento do encéfalo e, principalmente devido a sua atividade antioxidante, é possível que exerça um papel especial na prevenção e no manejo nutricional da doença de Parkinson. Atualmente, poucos pesquisadores têm investigado os efeitos do selênio sobre a doença de Parkinson. Entretanto, sabe-se que níveis corporais muito altos ou muito baixos de selênio podem (possivelmente) contribuir para a patogênese da doença de Parkinson, uma vez que esse desbalanço resulta no aumento dos níveis de estresse oxidativo. Dessa forma, o objetivo deste trabalho é revisar e discutir os estudos que abordaram esses tópicos e então associar as informações obtidas através deles para que esses dados e associações sejam usadas para o estabelecimento de novas pesquisas.

Palavras-chave: neurodegeneração, nutrição, estresse oxidativo, doença de Parkinson, selênio.

\section{REFERENCES}

ADAmS JR JD, Chang ML And Klaidman L. 2001. Parkinson's disease - redox mechanisms. Curr Med Chem 8: 809-814.

AGUILAR MV ET AL. 1998. Cerebrospinal fluid selenium and chromium levels in patients with Parkinson's disease. J Neural Transm 105: 1245-1251.

AKIL M, BiCER M, KiliC M, AVUnduK MC, MOGULKOC R AND BALTACI AK. 2011. Effect of intraperitoneal selenium administration on liver glycogen levels in rats 
subjected to acute forced swimming. Biol Trace Elem Res 139: 341-346.

ALIPANAH N, VARADHAN R, SUN K, FERRUCCI L, FRIED LP AND SEMBA RD. 2009. Low serum carotenoids are associated with a decline in walking speed in older women. J Nutr Health Aging 13: 170-175.

ARIGONY ALV, DE OLIVEIRA IM, MACHADO M, BORDIN DL, BERGTER L, PRÁ D AND HENRIQUES JAP. 2013. The influence of micronutrients in cell culture: a reflection on viability and genomic stability. Biomed Res Int 2013: 22.

AYUSO-PERALTA L, JIMÉNEZ-JIMÉNEZ FJ, CABRERAVALDiVia F, MOLINA JA, JAVIER MR, ALMAZÁN, DE PEDRO-Cuesta J, TABERnERo C AND GimÉneZRoldÁN S. 1997. Premorbid dietetic habits and risk for Parkinson's disease. Parkinsonism Relat Disord 3: 55-61.

BALTAZAR MT, DINIS-OLIVEIRA RJ, DE LOURDES BASTOS M, TSATSAKIS AM, DUARTE JA AND CARVALHO F. 2014. Pesticides exposure as etiological factors of Parkinson's disease and other neurodegenerative diseases - A mechanistic approach. Toxicol Lett 230: 85-103.

Barayuga SM, PAng X, Andres MA, PAneE J AND BELLINGER FP. 2013. Methamphetamine decreases levels of glutathione peroxidases 1 and 4 in SH-SY5Y neuronal cells: protective effects of selenium. Neurotoxicology 37 : 240-246.

BARNARD ND ET AL. 2014. Dietary and lifestyle guidelines for the prevention of Alzheimer's disease. Neurobiol Aging 35(Suppl 2): S74-S78.

BELLINGER FP ET AL. 2012. Changes in selenoprotein P in substantia nigra and putamen in Parkinson's disease. J Parkinsons Dis 2: 115-126.

BENTON D. 2002. Selenium intake, mood and other aspects of psychological functioning. Nutr Neurosci 5: 363-374.

BLAZINA T, SUN Y, VOEGELIN A, LENZ M, BERG M AND WINKEL LHE. 2014. Terrestrial selenium distribution in China is potentially linked to monsoonal climate. Nat Commun 5: 4717.

BOYD R. 2011. Selenium stories. Nat Chem 3: 570.

BRENNEISEN P, STEINBRENNER H AND SiES H. 2005. Selenium, oxidative stress, and health aspects. Mol Aspects Med 26: 256-267.

BRENNER S. 2014. Parkinson's disease may be due to failure of melanin in the Substantia Nigra to produce molecular hydrogen from dissociation of water, to protect the brain from oxidative stress. Med Hypotheses 82: 503.

BRIGELIUS-FLOHÉ R AND MAIORINO M. 2013. Glutathione peroxidases. Biochim Biophys Acta 1830: 3289-3303.

BROZMANOVÁ J, MÁNIKOVÁ D, VLČKOVÁ V AND CHOVANEC M. 2010. Selenium: a double-edged sword for defense and offence in cancer. Arch Toxicol 84: 919-938.

BURK RF AND HILL KE. 2009. Selenoprotein P - expression, functions, and roles in mammals. Biochim Biophys Acta 1790: 1441-1447.
BURK RF, HILL KE, MOTLEY AK, WINFREY VP, KUROKAWA S, Mitchell SL AND ZHANG W. 2014. Selenoprotein P and apolipoprotein E receptor-2 interact at the blood-brain barrier and also within the brain to maintain an essential selenium pool that protects against neurodegeneration. FASEB J 28: 3579-3588.

BYRNS CN, PITTS MW, GILMAN CA, HASHIMOTO AC AND BERRY MJ. 2014. Mice lacking selenoprotein P and selenocysteine lyase exhibit severe neurological dysfunction, neurodegeneration, and audiogenic seizures. J Biol Chem 289: 9662-9674.

CADET JL. 1986. The potential use of vitamin E and selenium in parkinsonism. Med Hypotheses 20: 87-94.

CAito SW, Milatovic D, HiLl KE, ASCHNER M, BURK RF AND VALENTINE WM. 2011. Progression of neurodegeneration and morphologic changes in the brains of juvenile mice with selenoprotein P deleted. Brain Res 1398: 1-12.

CANUGOVI C, MisiaK M, FERRARELLI LK, CROTEAU DL AND BOHR VA. 2013. The role of DNA repair in brain related disease pathology. DNA Repair (Amst) 12: 578-587.

CARDOSO BR, ROBERTS BR, BUSH AI AND HARE DJ. 2015. Selenium, selenoproteins and neurodegenerative diseases. Metallomics 7: 1213-1228.

CASTAÑO A, AYALA A, RODRÍGUEZ-GÓMEZ JA, HERRERA AJ, CANO J AND MACHADO A. 1997. Low selenium diet increases the dopamine turnover in prefrontal cortex of the rat. Neurochem Int 30: 549-555.

CElARDO I, MARTINS LM AND GANDHI S. 2014. Unravelling mitochondrial pathways to Parkinson's disease. Br J Pharmacol 171: 1943-1957.

CHAI C AND LIM KL. 2013. Genetic insights into sporadic Parkinson's disease pathogenesis. Curr Genomics 14: 486501.

CHEN J AND BERRY MJ. 2003. Selenium and selenoproteins in the brain and brain diseases. J Neurochem 86: 1-12.

Chen J, GuAN Z, WANG L, SONG G, MA B AND WANG Y. 2014. Meta-analysis: overweight, obesity, and Parkinson's disease. Int J Endocrinol 2014: 7.

ChIVA-Blanch G, BADIMON L AND ESTRUCH R. 2014. Latest evidence of the effects of the Mediterranean diet in prevention of cardiovascular disease. Curr Atheroscler Rep 16: 446.

COMBS JR GF. 2001. Selenium in global food systems. Br J Nutr 85: 517-547.

Cominetti C, De Bortoli MC, GARrido JR AB AND COZZOLINO SMF. 2012. Brazilian nut consumption improves selenium status and glutathione peroxidase activity and reduces atherogenic risk in obese women. Nutr Res 32: 403-407.

CORNETTA T, PALMA S, APRILE I, PADUA L, TONALI P, TESTA A AND COZZI R. 2009. Levodopa therapy reduces DNA damage in peripheral blood cells of patients with Parkinson's disease. Cell Biol Toxicol 25: 321-330. 
DAI D ET AL. 2014. Association of and polymorphisms with Parkinson's disease: A meta-analysis of 15 genetic association studies. Biomed Rep 2: 713-718.

DANIELS LA. 1996. Selenium metabolism and bioavailability. Biol Trace Elem Res 54: 185-199.

DAUER W AND PRZEDBORSKI S. 2003. Parkinson's disease: mechanisms and models. Neuron 39: 889-909.

DE LAU LML AND BRETELER MMB. 2006. Epidemiology of Parkinson's disease. Lancet Neurol 5: 525-535.

DEXTER DT AND JENNER P. 2013. Parkinson disease: from pathology to molecular disease mechanisms. Free Radic Biol Med 62: 132-144.

DiAS V, JUNN E AND MOURADIAN MM. 2013. The role of oxidative stress in Parkinson's disease. J Parkinsons Dis 3: 461-491.

DICKSON DW. 2012. Parkinson's disease and parkinsonism: neuropathology. Cold Spring Harb Perspect Med 2: a009258.

DONG J, BEARD JD, UMBACH DM, PARK Y, HUANG X, BLAIR A, KAMEL F AND CHEN H. 2014. Dietary fat intake and risk for Parkinson's disease. Mov Disord 29: 16231630.

DORSZEWSKA J, PRENDECKI M, LIANERI M AND KOZUBSKI W. 2014. Molecular effects of L-dopa therapy in Parkinson's disease. Curr Genomics 15: 11-17.

ELENBERG Y AND SHAOUL R. 2014. The role of infant nutrition in the prevention of future disease. Front Pediatr 2: 73.

EllWanger JH, MOLZ P, Dallemole DR, PEREIRA DOS SANTOS A, MÜLler TE, CAPPELlETti L, GONÇALVES DA SIlva M, FRANKE SIR, PRÁ D AND PÊGAS HENRIQUES JA. 2015. Selenium reduces bradykinesia and DNA damage in a rat model of Parkinson's disease. Nutrition 31: 359-365.

EllWANGer JH, PrÁ D, Rieger A AND Franke SIR. 2011. Influência do estado nutricional de selênio sobre a progressão da infecção pelo HIV. Nutrire 36: 109-122.

EsteVEZ AO, Mueller CL, MORGAN KL, SZEWCZYK NJ, TEECE L, MiRANDA-VizUETE A AND ESTEVEZ M. 2012. Selenium induces cholinergic motor neuron degeneration in Caenorhabditis elegans. Neurotoxicology 33: 10211032.

FERGUSON LR, KARUNASINGHE N, ZHU S AND WANG AH. 2012. Selenium and its' role in the maintenance of genomic stability. Mutat Res 733: 100-110.

FLAX VL ET AL. 2014. Plasma and breast-milk selenium in HIV-infected Malawian mothers are positively associated with infant selenium status but are not associated with maternal supplementation: results of the Breastfeeding, Antiretrovirals, and Nutrition study. Am J Clin Nutr 99: 950-956.

GAD MA AND ABD EL-TwAB SM. 2009. Selenium toxicosis assessment (in vivo and in vitro) and the protective role of vitamin B12 in male quail (Coturnix Coturnix). Environ Toxicol Pharmacol 27: 7-16.
GAKI GS AND PAPAVASSILIOU AG. 2014. Oxidative stressinduced signaling pathways implicated in the pathogenesis of Parkinson's disease. Neuromolecular Med 16: 217-230.

GAO X, SCHWARZSCHILD MA, O'REILLY EJ, WANG H AND ASCHERIO A. 2010. Restless legs syndrome and Parkinson's disease in men. Mov Disord 25: 2654-2657.

Giacosa A, Faliva MA, Perna S, Minoia C, Ronchi A AND RONDANELLI M. 2014. Selenium fortification of an Italian rice cultivar via foliar fertilization with sodium selenate and its effects on human serum selenium levels and on erythrocyte glutathione peroxidase activity. Nutrients 6: 1251-1261.

GIOVANNELLI L, DECOROSI F, DOLARA P AND PULVIRENTI L. 2003. Vulnerability to DNA damage in the aging rat substantia nigra: a study with the comet assay. Brain Res 969: 244-247.

GoEtz CG. 2011. The history of Parkinson's disease: early clinical descriptions and neurological therapies. Cold Spring Harb Perspect Med 1: a008862.

HART WE, MARCZAK SP, KNELLER AR, FRENCH RA AND MORRIS JR DL. 2013. The abilities of selenium dioxide and selenite ion to coordinate DNA-bound metal ions and decrease oxidative DNA damage. J Inorg Biochem 125: $1-8$.

HATFIELD DL, TSUJI PA, CARLSON BA AND GLADYSHEV VN. 2014. Selenium and selenocysteine: roles in cancer, health, and development. Trends Biochem Sci 39: 112120 .

HAUSER DN AND HAstings TG. 2013. Mitochondrial dysfunction and oxidative stress in Parkinson's disease and monogenic parkinsonism. Neurobiol Dis 51: 35-42.

HiLl KE, ZHOU J, MCMAHAN WJ, MOTLEY AK, ATKINS JF, GESTELAND RF AND BURK RF. 2003. Deletion of selenoprotein $\mathrm{P}$ alters distribution of selenium in the mouse. J Biol Chem 278: 13640-13646.

HWANG O. 2013. Role of oxidative stress in Parkinson's disease. Exp Neurobiol 22: 11-17.

IDE K ET AL. 2015. Lymphocyte vitamin C levels as potential biomarker for progression of Parkinson's disease. Nutrition 31: 406-408.

IMAM SZ AND ALI SF. 2000. Selenium, an antioxidant, attenuates methamphetamine-induced dopaminergic toxicity and peroxynitrite generation. Brain Res 855: 186-191.

IOM - INSTITUTE OF MEDICINE. 2000. Dietary Reference Intakes for Vitamin C, Vitamin E, Selenium, and Carotenoids. Food and Nutrition Board Whashington, DC: National Academies Press.

JANDA E, ISIDORO C, CARRESI C AND MOLlACE V. 2012. Defective autophagy in Parkinson's disease: role of oxidative stress. Mol Neurobiol 46: 639-661.

JEPPESEN DK, BOHR VA AND STEVNSNER T. 2011. DNA repair deficiency in neurodegeneration. Prog Neurobiol 94: 166-200. 
JIANG W, JU C, JIANG H AND ZHANG D. 2014. Dairy foods intake and risk of Parkinson's disease: a dose-response meta-analysis of prospective cohort studies. Eur J Epidemiol 29: 613-619.

KAMEL F. 2013. Paths from pesticides to Parkinson's. Science 341: 722-723.

KAMEL F ET AL. 2014. Dietary fat intake, pesticide use, and Parkinson's disease. Parkinsonism Relat Disord 20: 82-87.

KHAN HA. 2010. Selenium partially reverses the depletion of striatal dopamine and its metabolites in MPTP-treated C57BL mice. Neurochem Int 57: 489-491.

KIM HC, JHOO WK, CHOI DY, IM DH, SHIN EJ, SUH JH, FLOYD RA AND BING G. 1999. Protection of methamphetamine nigrostriatal toxicity by dietary selenium. Brain Res 851: 76-86.

Kirbas A, Kirbas S, CURE MC AND TUfeKCi A. 2014. Paraoxonase and arylesterase activity and total oxidative/ anti-oxidative status in patients with idiopathic Parkinson's disease. J Clin Neurosci 21: 451-455.

KONDO K ET AL. 2014. A high-fiber, low-fat diet improves periodontal disease markers in high-risk subjects: a pilot study. Nutr Res 34: 491-498.

KOUTI L, NOROOZIAN M, AKHONDZADEH S, ABDOLLAHI M, JAVADI MR, FARAMARZI MA, MOUSAVI S AND GHAELI P. 2013. Nitric oxide and peroxynitrite serum levels in Parkinson's disease: correlation of oxidative stress and the severity of the disease. Eur Rev Med Pharmacol Sci 17: 964-970.

KOWAL SL, DALL TM, CHAKRABARTI R, STORM MV AND JAIN A. 2013. The current and projected economic burden of Parkinson's disease in the United States. Mov Disord 28: 311-318.

KRISTAL AR ET AL. 2014. Baseline selenium status and effects of selenium and vitamin e supplementation on prostate cancer risk. J Natl Cancer Inst 106: djt456.

LABBÉ C AND Ross OA. 2014. Association studies of sporadic Parkinson's disease in the genomic era. Curr Genomics 15: 2-10.

LAMARCHE F, SIGNORINI-ALLIBE N, GONTHIER B AND BARRET L. 2004. Influence of vitamin E, sodium selenite, and astrocyte-conditioned medium on neuronal survival after chronic exposure to ethanol. Alcohol 33: 127-138.

LEES AJ, HARDY J AND REVESZ T. 2009. Parkinson's disease. Lancet 373: 2055-2066.

LEI XG, CHENG WH AND MCCLUNG JP. 2007. Metabolic regulation and function of glutathione peroxidase-1. Annu Rev Nutr 27: 41-61.

LEMIRE M, FILLION M, BARBOSA JR F, GUIMARÃES JR AND MERGLER D. 2010. Elevated levels of selenium in the typical diet of Amazonian riverside populations. Sci Total Environ 408: 4076-4084.

Lemire M, Fillion M, Frenette B, Passos CJS, GuimarÃes JR, BARbosa JR F AND MERGLER D. 2011.
Selenium from dietary sources and motor functions in the Brazilian Amazon. Neurotoxicology 32: 944-953.

LETAVAYOVÁ L, VLČKOVÁ V AND BROZMANOVÁ J. 2006. Selenium: from cancer prevention to DNA damage. Toxicology 227: 1-14.

LEWITT PA, Li J, LU M, BEACH TG, ADLER CH, GUO L AND ARIZONA PARKINSON'S DISEASE CONSORTIUM. 2013. 3-hydroxykynurenine and other Parkinson's disease biomarkers discovered by metabolomic analysis. Mov Disord 28: 1653-1660.

Li X, YIN D, Yin J, CHEN Q AND WANG R. 2014. Dietary selenium protect against redox-mediated immune suppression induced by methylmercury exposure. Food Chem Toxicol 72: 169-177.

LI WH, SHI YC, TSENG IL AND LIAO VHC. 2013. Protective efficacy of selenite against lead-induced neurotoxicity in Caenorhabditis elegans. PLoS ONE 8: e62387.

LIU ZW, ZHU HT, CHEN KL, QIU C, TANG KF AND NIU XL. 2013. Selenium attenuates high glucose-induced ROS/ TLR-4 involved apoptosis of rat cardiomyocyte. Biol Trace Elem Res 156: 262-270.

LOGROSCINO G, GAO X, CHEN H, WING A AND ASCHERIO A. 2008. Dietary iron intake and risk of Parkinson's disease. Am J Epidemiol 168: 1381-1388.

LosCALZO J. 2014. Keshan disease, selenium deficiency, and the selenoproteome. N Engl J Med 370: 1756-1760.

LU Z ET AL. 2014. Altered selenium status in Huntington's disease: neuroprotection by selenite in the N171-82Q mouse model. Neurobiol Dis 71: 34-42.

LUBOMSKI M, LOUISE RUSHWORTH R, LEE W, BERTRAM KL AND WILLIAMS DR. 2014. Sex differences in Parkinson's disease. J Clin Neurosci 21: 1503-1506.

MACHADO MS, ROSA RM, DANTAS AS, REOLON GK, APPELT HR, BRAGA AL, HENRIQUES JAP AND ROESLER R. 2006. An organic selenium compound attenuates apomorphine-induced stereotypy in mice. Neurosci Lett 410: 198-202.

MALDONADO PD ET AL. 2012. Selenium-induced antioxidant protection recruits modulation of thioredoxin reductase during excitotoxic/pro-oxidant events in the rat striatum. Neurochem Int 61: 195-206.

MARALDI T, RiCCIO M, ZAMBONIN L, VINCETI M, DE POL A AND HAKIM G. 2011. Low levels of selenium compounds are selectively toxic for a human neuron cell line through ROS/RNS increase and apoptotic process activation. Neurotoxicology 32: 180-187.

MARCONDES SARI MH, GUERRA SOUZA AC, GONÇALVES ROSAS,SOUZAD,DORNELESRODRIGUESOEANDWAYNE NOGUEIRA C. 2014. Contribution of dopaminergic and adenosinergic systems in the antinociceptive effect of p-chloro-selenosteroid. Eur J Pharmacol 725: 79-86.

MARTIN I, KIM JW, DAWSON VL AND DAWSON TM. 2014. LRRK2 pathobiology in Parkinson's disease. J Neurochem 131: 554-565. 
MAZZONI P, SHABBotT B AND CORTÉS JC. 2012. Motor control abnormalities in Parkinson's disease. Cold Spring Harb Perspect Med 2: a009282.

MCCORMACK AL, THIRUCHELVAM M, MANNING-BOG AB, ThifFAult C, LANGSTON JW, CORY-SLECHTA DA AND DI MONTE DA. 2002. Environmental risk factors and Parkinson's disease: selective degeneration of nigral dopaminergic neurons caused by the herbicide paraquat. Neurobiol Dis 10: 119-127.

Mehanna R, Moore S, Hou JG, SARwar AI AND LAi EC. 2014. Comparing clinical features of young onset, middle onset and late onset Parkinson's disease. Parkinsonism Relat Disord 20: 530-534.

MEHDI Y, HORNICK JL, ISTASSE L AND DUFRASNE I. 2013. Selenium in the environment, metabolism and involvement in body functions. Molecules 18: 3292-3311.

Miorelli ST, Rosa RM, MOURA DJ, ROCHA JC, LOBO LAC, HENRIQUES JAP AND SAFFI J. 2008. Antioxidant and anti-mutagenic effects of ebselen in yeast and in cultured mammalian V79 cells. Mutagenesis 23: 93-99.

Mischley LK, ALLEN J AND BRADLEY R. 2012. Coenzyme Q10 deficiency in patients with Parkinson's disease. J Neurol Sci 318: 72-75.

MOREIRA PL, VILLAS BOAS PJF AND FERREIRA ALA. 2014. Association between oxidative stress and nutritional status in the elderly. Rev Assoc Med Bras 60: 75-83.

MÜller SK, BENDER A, LAUB C, HÖGEN T, SCHLAUdRAFF F, Liss B, KLOPSTOCK T AND ELSTNER M. 2013. Lewy body pathology is associated with mitochondrial DNA damage in Parkinson's disease. Neurobiol Aging 34: 22312233.

NALLS MA ET AL. 2014. Large-scale meta-analysis of genome-wide association data identifies six new risk loci for Parkinson's disease. Nat Genet 46: 989-993.

NAVARRO-ALARCON M AND CABRERA-VIQUE C. 2008. Selenium in food and the human body: a review. Sci Total Environ 400: 115-141.

NAZIROĞLU M, ŞENOL N, GHAZIZADEH V AND YÜRÜKER V. 2014. Neuroprotection induced by $N$-acetylcysteine and selenium against traumatic brain injury-induced apoptosis and calcium entry in hippocampus of rat. Cell Mol Neurobiol 34: 895-903.

NiKAM S, NiKAM P, AHALEY SK AND SONTAKKE AV. 2009. Oxidative stress in Parkinson's disease. Indian J Clin Biochem 24: 98-101.

NIRANJAN R. 2014. The role of inflammatory and oxidative stress mechanisms in the pathogenesis of Parkinson's disease: focus on astrocytes. Mol Neurobiol 49: 28-38.

NOGUEIRA CW AND ROCHA JBT. 2011. Toxicology and pharmacology of selenium: emphasis on synthetic organoselenium compounds. Arch Toxicol 85: 1313-1359.

NusSBAUM RL AND ELLIS CE. 2003. Alzheimer's disease and Parkinson's disease. N Engl J Med 348: 1356-1364.
OTHMAN AI AND EL MISSIRY MA. 1998. Role of selenium against lead toxicity in male rats. J Biochem Mol Toxicol 12: 345-349.

PARLATO R AND LISS B. 2014. How Parkinson's disease meets nucleolar stress. Biochim Biophys Acta 1842: 791-797.

Peters MM, HiLl KE, BURK RF AND WeEBER EJ. 2006. Altered hippocampus synaptic function in selenoprotein $\mathrm{P}$ deficient mice. Mol Neurodegener 1: 12.

PETERSON AL. 2014. A review of vitamin D and Parkinson's disease. Maturitas 78: 40-44.

PILlAi R, UYEHARA-LOCK JH AND BELLINGER FP. 2014. Selenium and selenoprotein function in brain disorders. IUBMB Life 66: 229-239.

PITTS MW, BYRNS CN, OGAWA-WONG AN, KREMER P AND BERRY MJ. 2014. Selenoproteins in nervous system development and function. Biol Trace Elem Res 161: 231-245.

Pringsheim T, JetTe N, Frolkis A AND SteEVES TD. 2014. The prevalence of Parkinson's disease: a systematic review and meta-analysis. Mov Disord 29: 1583-1590.

QURESHI GA, QURESHI AA, MEMON SA AND PARVEZ SH. 2006. Impact of selenium, iron, copper and zinc in on/off Parkinson's patients on L-dopa therapy. J Neural Transm 71(Suppl): 229-236.

RAHIMDEL AG, AYATOLLAHI P, ZEINALI A, MEHRABANIAN N AND MELLAT-ARDEKANI A. 2012. The effect of selenium administration on restless leg syndrome treatment. Iran Red Crescent Med J 14: 14-19.

RAHMANTO AS AND DAVIES MJ. 2012. Selenium-containing amino acids as direct and indirect antioxidants. IUBMB Life 64: 863-871.

RAYMAN MP. 2012. Selenium and human health. Lancet 379: 1256-1268.

RAYMAN MP, INFANTE HG AND SARGENT M. 2008. Foodchain selenium and human health: spotlight on speciation. Br J Nutr 100: 238-253.

RODRÍGUEZ-LEYVA ET AL. 2014. $\alpha$-Synuclein inclusions in the skin of Parkinson $>$ disease and parkinsonism. Ann Clin Transl Neurol 1: 471-478.

ROMAN M, JiTARU P AND BARBANTE C. 2014. Selenium biochemistry and its role for human health. Metallomics 6: 25-54.

ROMERO-RAMOS M, VENERO JL, CANO J AND MACHADO A. 2000. Low selenium diet induces tyrosine hydroxylase enzyme in nigrostriatal system of the rat. Brain Res Mol Brain Res 84: 7-16.

SAITO Y. 2014. Oxidized DJ-1 as a possible biomarker of Parkinson's disease. J Clin Biochem Nutr 54: 138-144.

SANCHEZ V, CAMARERo J, O'ShEA E, GREEN AR AND COLADO MI. 2003. Differential effect of dietary selenium on the long-term neurotoxicity induced by MDMA in mice and rats. Neuropharmacology 44: 449-461.

SANDERS LH AND GREENAMYRE JT. 2013. Oxidative damage to macromolecules in human Parkinson disease and the rotenone model. Free Radic Biol Med 62: 111-120. 
SANDERS LH, MCCOY J, HU X, MASTROBERARDINO PG, DiCKINSON BC, CHANG CJ, CHU CT, VAN HOUTEN B AND GREENAMYRE JT. 2014. Mitochondrial DNA damage: molecular marker of vulnerable nigral neurons in Parkinson's disease. Neurobiol Dis 70: 214-223.

SCHWEIZER U, BRÄUER AU, KÖHRLE J, Nitsch R AND SAVASKAN NE. 2004. Selenium and brain function: a poorly recognized liaison. Brain Res Brain Res Rev 45: 164-178.

SEARLES NiELSEN S, BAMMLER TK, GALlAGHER LG, FARIN FM, LONGSTRETH JR WT, FRANKLIN GM, SWANSON PD AND CHECKOWAY H. 2013. Genotype and age at Parkinson disease diagnosis. Int J Mol Epidemiol Genet 4: 61-69.

SEET RCS ET AL. 2010. Oxidative damage in Parkinson disease: Measurement using accurate biomarkers. Free Radic Biol Med 48: 560-566.

ŞENOL N, NAZIROĞLU M AND YÜRÜKER V. 2014. N-acetylcysteine and selenium modulate oxidative stress, antioxidant vitamin and cytokine values in traumatic brain injuryinduced rats. Neurochem Res 39: 685-692.

Shahar A, PATEl KV, SEMba RD, BAndinelli S, SHAHAR DR, FERRUCCI L AND GURALNIK JM. 2010. Plasma selenium is positively related to performance in neurological tasks assessing coordination and motor speed. Mov Disord 25: 1909-1915.

SHCHEDRINA VA, EVERLEY RA, ZHANG Y, GYGI SP, HATFIELD DL AND GLADYSHEV VN. 2011. Selenoprotein $\mathrm{K}$ binds multiprotein complexes and is involved in the regulation of endoplasmic reticulum homeostasis. J Biol Chem 286: 42937-42948.

SMEYNE M AND SMEYNE RJ. 2013. Glutathione metabolism and Parkinson's disease. Free Radic Biol Med 62: 13-25.

SONG E ET AL. 2014. Selenium supplementation shows protective effects against patulin-induced brain damage in mice via increases in GSH-related enzyme activity and expression. Life Sci 109: 37-43.

SPECKMANN B AND GRUNE T. 2015. Epigenetic effects of selenium and their implications for health. Epigenetics 10: 179-190.

SQUiTTI R, SIOTTO M AND POLIMANTI R. 2014. Low-copper diet as a preventive strategy for Alzheimer's disease. Neurobiol Aging 35(Suppl 2): S40-S50.

STEINBRENNER H AND SIES H. 2013. Selenium homeostasis and antioxidant selenoproteins in brain: implications for disorders in the central nervous system. Arch Biochem Biophys 536: 152-157.

STELMASHOOK EV, ISAEV NK, GENRIKHS EE, AMELKINA GA, KhASPEKOV LG, SKREBitsky VG AND ILLARIOSHKIN SN. 2014. Role of zinc and copper ions in the pathogenetic mechanisms of Alzheimer's and Parkinson's diseases. Biochemistry (Mosc) 79: 391-396.

Stockler-PINTO MB, MAFra D, FARAGE NE, BOAVENTURA GT AND COZZOLINO SMF. 2010. Effect of
Brazil nut supplementation on the blood levels of selenium and glutathione peroxidase in hemodialysis patients. Nutrition 26: 1065-1069.

SUBRAMANIAM SR AND CHESSELET MF. 2013. Mitochondrial dysfunction and oxidative stress in Parkinson's disease. Prog Neurobiol 106-107: 17-32.

SUDFELD CR, ABOUD S, KUPKA R, MUGUSI FM AND FAWZI WW. 2014. Effect of selenium supplementation on HIV1 RNA detection in breast milk of Tanzanian women. Nutrition 30: 1081-1084.

TANNER CM ET AL. 2011. Rotenone, paraquat, and Parkinson's disease. Environ Health Perspect 119: 866-872.

TAYLOR JM, MAIN BS AND CRACK PJ. 2013. Neuroinflammation and oxidative stress: co-conspirators in the pathology of Parkinson's disease. Neurochem Int 62: 803-819.

THIRY C, SCHNEIDER YJ, PUSSEMIER L, DE TEMMERMAN L AND RUTTENS A. 2013. Selenium bioaccessibility and bioavailability in Se-enriched food supplements. Biol Trace Elem Res 152: 152-160.

THOMSON CD. 2004. Assessment of requirements for selenium and adequacy of selenium status: a review. Eur J Clin Nutr 58: 391-402.

TIAN L, ZHANG S, XU L, LI W, WANG Y, CHEN W, DING J AND CHEN S. 2012. Selenite benefits embryonic stem cells therapy in the animal models of Parkinson's disease through inhibiting inflammation. Mol Neurodegener 7(Suppl 1): L25.

TSANG AHK AND CHUNG KKK. 2009. Oxidative and nitrosative stress in Parkinson's disease. Biochim Biophys Acta 1792: 643-650.

VIEIRA ROCHA A, CARDOSO BR, COMINETTI C, BUENO RB, DE BORTOLI MC, FARIAS LA, FAVARO DIT, CAMARGO LMA AND COZZOLINO SMF. 2014. Selenium status and hair mercury levels in riverine children from Rondonia, Amazonia. Nutrition 30: 1318-1323.

VINCETI M, MANDRIOLI J, BORELLA P, MICHALKE B, TSATSAKIS A AND FINKELSTEIN Y. 2014. Selenium neurotoxicity in humans: bridging laboratory and epidemiologic studies. Toxicol Lett 230: 295-303.

VINCETI M, NACCI G, ROCCHI E, CASSINADRI T, VIVOLI R, MARCHESI C AND BERGOMI M. 2000. Mortality in a population with long-term exposure to inorganic selenium via drinking water. J Clin Epidemiol 53: 1062-1068.

Wang A, Costello S, CockBurn M, Zhang X, BRONSTEIN J AND RITZ B. 2011. Parkinson's disease risk from ambient exposure to pesticides. Eur J Epidemiol 26: 547-555.

WANG D, ZHAI JX, ZHANG LM AND LIU DW. 2014. Null genotype of GSTT1 contributes to increased Parkinson's disease risk in Caucasians: evidence from a meta-analysis. Mol Biol Rep 41: 7423-7430.

WATANABE C, KASANUMA Y AND SATOH H. 1997. Deficiency of selenium enhances the $\mathrm{K}+$-induced release of dopamine in the striatum of mice. Neurosci Lett 236: 49-52. 
WATANABE C AND SATOH H. 1994. Brain selenium status and behavioral development in selenium-deficient preweanling mice. Physiol Behav 56: 927-932.

WEEKS BS, HANNA MS AND COOPERSTEIN D. 2012. Dietary selenium and selenoprotein function. Med Sci Monit 18: RA127-RA132.

WEN Z, SHU Y, GAO C, WANG X, QI G, ZHANG P, LI M, SHI J AND TIAN B. 2014. CDK5-mediated phosphorylation and autophagy of RKIP regulate neuronal death in Parkinson's disease. Neurobiol Aging 35: 2870-2880.

YAKUBOV E, BUCHFELDER M, EYÜPOGLU IY AND SAVASKAN NE. 2014. Selenium action in neuro-oncology. Biol Trace Elem Res 161: 246-254.

YAN MH, WANG X AND ZHU X. 2013. Mitochondrial defects and oxidative stress in Alzheimer disease and Parkinson disease. Free Radic Biol Med 62: 90-101.

YANG X, BAO Y, FU H, LI L, REN T AND YU X. 2014. Selenium protects neonates against neurotoxicity from prenatal exposure to manganese. PLoS ONE 9: e86611.

YEN GC AND HSIEH CL. 1997. Antioxidant effects of dopamine and related compounds. Biosci Biotechnol Biochem 61: 1646-1649.

YEO JE, KIM JH AND KANG SK. 2008. Selenium attenuates ROS-mediated apoptotic cell death of injured spinal cord through prevention of mitochondria dysfunction; in vitro and in vivo study. Cell Physiol Biochem 21: 225-238.

YOUNES-MHENNI S ET AL. 2013. Serum copper, zinc and selenium levels in Tunisian patients with Parkinson's disease. Tunis Med 91: 402-405.

YU H, STERnAd D, CORCOS DM AND VAILlanCOURT DE. 2007. Role of hyperactive cerebellum and motor cortex in Parkinson's disease. Neuroimage 35: 222-233.

ZAFAR KS, SIDDIQUI A, SAYEED I, AHMAD M, SALIM S AND ISLAM F. 2003. Dose-dependent protective effect of selenium in rat model of Parkinson's disease: neurobehavioral and neurochemical evidences. J Neurochem 84: 438-446.

ZHANG H, DUAN C AND YANG H. 2015. Defective autophagy in Parkinson's disease: lessons from genetics. Mol Neurobiol 51: 89-104.

Zhang Q, Chen L, GuO K, Zheng L, LiU B, YU W, GUO C, LIU Z, CHEN Y AND TANG Z. 2013. Effects of different selenium levels on gene expression of a subset of selenoproteins and antioxidative capacity in mice. Biol Trace Elem Res 154: 255-261.

ZHANG S, ROCOURT C AND CHENG WH. 2010. Selenoproteins and the aging brain. Mech Ageing Dev 131: 253-260.

ZHAO HW, LIN J, WANG XB, CHENG X, WANG JY, HU BL, ZHANG Y, ZHANG X AND ZHU JH. 2013. Assessing plasma levels of selenium, copper, iron and zinc in patients of Parkinson's disease. PLoS ONE 8: e83060.

ZUO L AND MOTHERWELL MS. 2013. The impact of reactive oxygen species and genetic mitochondrial mutations in Parkinson's disease. Gene 532: 18-23. 